\section{Kinga Frąckowska}

Uniwersytet Mikołaja Kopernika w Toruniu

email: kinga.frackowska@op.pl

DOI: http://dx.doi.org/10.12775/BPTh.2017.003

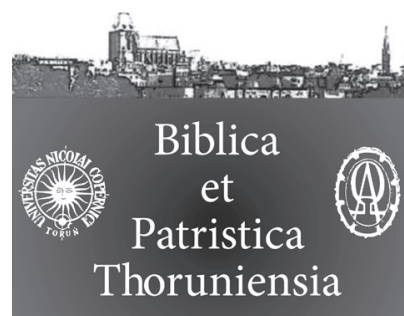

10 (2017) 1: 65-76

ISSN (print) 1689-5150

ISSN (online) 2450-7059

\title{
Gatunek literacki Ez 17 - słowo proroka czy mędrca?
}

\section{The literary genre of Eze 17 - word of a prophet or a sage?}

Streszczenie. Znaczącą rolę przy odkrywaniu orędzia tekstów biblijnych odgrywają gatunki literackie, w których zostały spisane. W 17 rozdziale Księgi Ezechiela spotykamy się z terminem māšāl, który wskazuje na przysłowie, przypowieść czy alegorię i odsyła czytelnika do tekstów wywodzących się z tradycji mądrościowej obecnych w Piśmie Świętym. Praca została poświęcona przywołaniu podstawowych gatunków literackich określanych mianem māšāl, aby na tym tle podjąć próbę zdefiniowania gatunku literackiego Ez 17 oraz odpowiedzieć na pytanie, czy omawiany tekst z Księgi Ezechiela zawiera wypowiedź prorocką czy mądrościową. W celu przybliżenia przesłania Ez 17 przedstawiono wewnętrzną dynamikę całego rozdziału oraz zasygnalizowano kontekst historyczny jego powstania.

\begin{abstract}
In the 17th chapter of the Book of Ezekiel we meet the word "māšāl", which indicates a proverb, a parable or an allegory, and refers the reader to the texts derived from the wisdom tradition present in the Scriptures. This paper recalls the basic literary genres known as māšāl, it is also an attempt to define the genre of Eze 17. The author answers the question whether the present text of the Book of Ezekiel contains a prophetic word or a word of wisdom. To show the message of Ezekiel 17 the author reveals the internal dynamics of the whole chapter and evokes the historical context of writing Eze 17.
\end{abstract}

Słowa kluczowe: Ezechiel; prorok; mędrzec; alegoria; māšāl; Księga Ezechiela; gatunek literacki; tradycja mądrościowa.

Keywords: Ezekiel; the prophet; sage; allegory; māšāl; the Book of Ezekiel; a literary genre; wisdom tradition. 
W Konstytucji dogmatycznej o Objawieniu Bożym Dei Verbum spotykamy się z zaleceniem, by poszukując właściwego sensu tekstów zawartych w Piśmie Świętym dociekać, co naprawdę zamierzano w nich przekazać. Dokument poucza, by odkrywając znaczenie słów zawartych na kartach Pisma, uwzględnić gatunki literackie, za pomocą których utrwalono treści objawione przez Boga, ponieważ teksty różnego typu w odmienny sposób wyrażają przekazywane przez siebie prawdy ${ }^{1}$.

W rozdziale 17 Księgi Ezechiela spotykamy się z terminem māšāl (Ez 17,2), który w Starym Testamencie może kojarzyć się z tekstami wywodzącymi się z tradycji mądrościowej i odsyłać nas do Księgi Przysłów ${ }^{2}$. Czy jednak treść Ez 17 stanowi wypowiedź sapiencjalną? Zanim spróbujemy odpowiedzieć na to pytanie, przyjrzymy się pokrótce podstawowym starotestamentalnym rodzajom literackim określanym jako məšālîm. Następnie dokonamy analizy struktury Ez 17, przyjrzymy się tematom poruszanym w treści opowiadania oraz jego kontekstowi historycznemu. Zwieńczeniem pracy będzie próba udzielenia odpowiedzi na pytanie, czy Ez 17 jest przykładem opowiadania mądrościowego czy właściwego dla proroka.

\section{Māšāl w Starym Testamencie}

\subsection{Māšāl w tradycji mądrościowej}

Termin māšāl pojawia się 39 razy na kartach Biblii hebrajskiej. Z 1 Krl 5,12 dowiadujemy się, że Salomon miał wypowiedzieć trzy tysiące məšālîm, a początek Księgi Przysłów informuje czytelnika o zebraniu wypowiedzi Salomona (o charakterze məšālîm) w obszerną księgę liczącą 31 rozdziałów. Lektura Księgi Przysłów pozwala zauważyć, że słowo māšāl jest terminem o szerokim zakresie znaczeń, obejmującym zarówno przysłowia, krótkie jasno sformułowane powiedzenia, ale też dłuższe rady mądrościowe, instrukcje oraz objawienia ${ }^{3}$. Do właściwego odczytania niektórych tekstów zwanych məšālîm konieczny jest dostateczny poziom inteligencji, ale też pomoc Boga, ponieważ māšāl może mieć charakter enigmatyczny, a jego znaczenie może być ukryte ${ }^{4}$.

1 Por. Konstytucja o Objawieniu Bożym Dei Verbum, nr 12.

2 Zob. początek Księgi Przysłów w języku hebrajskim - Prz 1,1: Mišəlê Šəlōmōḥ benDāwid melek Yiśərā’e ēl. W Ez 17,2 termin māšāl pojawia się obok pojęcia hîidâh (zagadka). Z podobnym zestawieniem mamy do czynienia również $\mathrm{w} \operatorname{Prz}$ 1,6.

3 Por. R. Meynet, Język przypowieści biblijnych, s. 9.

4 Por. ibidem, s. 11. 
W Księdze Przysłów spotykamy dłuższe wypowiedzi o charakterze przysłów, złożone z kilku następujących po sobie wersetów np.: „Nie zazdrość złym ludziom, nie pragnij ich towarzystwa/ bo serce ich przemoc obmyśla, ich wargi mówią o krzywdzie" (Prz 24,1-2), ale już pojedyncze wersety mogą prezentować powiedzenie, którego kompozycja opiera się na konstrukcji paralelizmu synonimicznego czy antytetycznego: „Gdzie bydła brak, tam spichlerz pusty, dzięki mocy wołów plon jest obfity” (Prz 14,4), „Lepszy kęs chleba w spokoju niż dom pełen biesiad kłótliwych" (Prz 17,1).

Warto zastanowić się, jaki był cel komponowania wypowiedzi mądrościowych. Według Prz 1,1-7 māšāl ma służyć odkrywaniu, nabieraniu mądrości i przekazywaniu jej innym także za pomocą wypowiedzi niejasnych, aluzyjnych i zagadkowych. Mędrcy, przez obserwację świata, przyrody, działań ludzkich, poszukiwali ładu w świecie i życiu człowieka. Ich zalecenia miały na celu kształtowanie cnoty, kierowanie się mądrością zrodzoną z doświadczenia - także w wykonywaniu zwyczajnych, codziennych czynności. Postępowanie pełne mądrości miałoby owocować pokojem i harmonią w życiu. Należy zaznaczyć, że w porównaniach, metaforach czy przysłowiach sapiencjalnych nie odnajdujemy mów kierowanych do tłumnie zgromadzonego ludu czy zebrania liturgicznego, żarliwych przemówień etycznych, emocjonalnie skomponowanych nawoływań do nawrócenia ${ }^{5}$.

\subsection{Māšāl w pozostałych pismach Starego Testamentu}

Wypowiedzi, które można określić za pomocą słowa māšāl nie są charakterystyczne tylko dla tekstów biblijnych związanych z tradycją mądrościową. Wspomniany termin pojawia się także w księgach historycznych Starego Testamentu czy w pismach prorockich.

Māšāl jako przysłowie czy powiedzenie pojawia się m.in. w 1 Sm 24,13-14, gdy Dawid mimo nadarzającej się okazji, nie zabija prześladującego go Saula i wypowiada słowa: „Moja ręka nie zwróci się przeciw tobie”. Z przysłowiami mamy też do czynienia w księgach prorockich, zarówno Jeremiasz jak i Ezechiel przywołują powtarzane wówczas wśród ludu słowa: „Ojcowie jedli cierpkie jagody, synom zdrętwiały zęby” (Jr 31,29-30; Ez 18,2). W Księdze Ezechiela spotykamy też powiedzenie, które negatywnie ocenia postawę Izraela wobec Boga w historii: „Jaka matka, taka córka” $(\mathrm{Ez} 16,44)^{6}$.

5 Por. T. Brzegowy, Pisma mądrościowe Starego Testamentu, s. 15-16.

6 Por. E.J. Jezierska, Mašal w tekstach Starego Testamentu, s. 187. Negatywną ocenę Izraela można odczytać z następujących po przytoczonym powodzeniu słowach proroka: 
Termin māšāl określa także zagadkę, jak w Sdz 14,14 czy Jr 23,9-40. W Księdze Sędziów Samson, mając w pamięci zabitego lwa, w którego ciele znalazł miód, zadaje zagadkę Filistynom: „Z tego, co pożera, wyszło to, co jest spożywane, a z mocnego wyszła słodycz", a Jeremiasz mówiąc o prawdziwych i fałszywych prorokach pyta: „Co ma wspólnego słoma z ziarnem”. Proroctwa i błogosławieństwa Baalama zawarte w 23 i 24 rozdziale Księgi Liczb również określane są mianem māšālu. Termin ten w Starym Testamencie oznacza ponadto przypowieść (2 Sm 12,1-4 - opowieść Natana wygłoszona Dawidowi), alegorię (Iz 5,1-17 pieśń o winnicy), bajkę (Sdz 9,7-15 - bajka Jotama o drzewach wybierających króla) oraz nauczanie (Ps 78 - gdzie māšāl związany jest z nauczaniem - tôrāh i tajemnicą - hîdāh $)^{8}$.

Przytoczone przykłady występowania terminu māšāl, pokazują jego szerokie zastosowanie oraz pozwalają zauważyć, że māšāl to nie tylko przysłowie. To również zagadki, przypowieści, alegorie czy bajki pojawiające się w księgach historycznych i prorockich.

\section{Kompozycja Ez 17 i trudności w określeniu gatunku literackiego}

Komentatorzy biblijni traktują Ez 17 jako całość, w której można wyróżnić trzy kluczowe sekcje: ww. 1-10, 11-21 oraz $22-24^{9}$. Pierwszy i trzeci z podanych fragmentów zostały zapisane na sposób liryczny, językiem obrazowym ${ }^{10}$,

„Jesteś rzeczywiście córką swej matki, która zdradziła swego męża i dzieci, jesteś rzeczywiście siostrą swych sióstr, które zdradziły swoich mężów i dzieci”. Ez 16,45.

7 Por. ibidem, s. 188-189.

8 Por. ibidem, s.191-194.

9 Por. W. Zimmerli, Ezekiel 1. A Commentary on the Book of the Prophet Ezekiel, Chapters 1-24, s. 361-368; R.M. Hals, Ezekiel, s. 223-231; L.C. Allen, Ezekiel 1-19, Word Biblical Commentary, s. 255-256; J. Blenkinsopp, Ezekiel, s. 81-82; Moshe Greenberg oraz Daniel I. Block w rozdziale 17 wyróżniają cztery powiazane ze sobą fragmenty: 1-10, 11-18, 19-21 oraz 22-24. Zob. M. Greenberg, Ezekiel 1-20, s. 320 oraz D.I Block, The Book of Ezekiel: Chapters 1-24.

10 Walther Zimmerli i Moshe Greenberg zauważają poetycką strukturę fragmentu Ez 17, 1-10. Zimmerli wskazuje na kluczową funkcję konstrukcji chiastycznej omawianej sekcji oraz dostrzegalną w niej rytmizację. Por. W. Zimmerli, Ezekiel 1, s. 359. Greenberg natomiast podkreśla znaczącą rolę paralelizmów obecnych w tekście. Por. M. Greenberg, Ezekiel 1-20, s. 318. Za poetyckim charakterem tekstu opowiada się również George A. Cooke, twierdząc, że ww. 3-10 stanowią wiersz, w którym przy odrobinie wysiłku można podjąć próbę wyróżnienia sześciu strof. Por. G.A. Cooke, A Critical and Exegetical Commentary on the Book Ezekiel, s. 181-182. Innego zdania jest Ronald M. Hals, twierdząc, że stosowanie paralelizmów nadaje tekstowi jedynie charakteru podniosłej prozy. Por. R.M. Hals, Ezekiel, s. 115. 
ww. 11-21 natomiast spisano prozą. Powszechnie dominuje opinia, że ww. 1-10 zawierają barwną alegorię, którą słuchacze mają okazję odnieść do znanych im wydarzeń historycznych i sytuacji, w której się znajdują ${ }^{11}$.

Treść Ez 17 układa się zatem w sposób następujący: w. 1 zawiera charakterystyczną dla pism prorockich formułę wydarzenia słowa („Pan skierował do mnie te słowa”), w w. 2-10 odnajdujemy wypowiedzianą na polecenie Boga alegoryczną opowieść o orle (nešer), cedrze ('erez) i winorośli (gepen). Fragment 11-21 rozpoczyna się od powtórzenia formuły prorockiej („Pan skierował do mnie te słowa") a następnie podaje słuchaczom jednoznaczną, historyczną interpretację usłyszanej wcześniej opowieści oraz „opinię” Boga na temat politycznych poczynań Sedecjasza. W w. 22 spotykamy prorocką formułę posłańca („tak mówi Pan Bóg” - jak w w. 19 dzielącym fragment 11-21 na dwie części), która wprowadza do kolejnej historii zapowiadającej rozwój cedru zasadzonego przez Boga, a całość rozdziału 17 zamyka formuła rozpoznania w w. 24 rozbudowana o dwa paralelizmy antytetyczne („I wszystkie drzewa na polu poznają, że ja jestem Pan [...]. Ja Pan rzekłem i to uczynię").

Chcąc jednoznacznie ustalić, w jaki gatunek literacki wpisuje się treść Ez 17, natrafimy na liczne wątpliwości. Po pierwsze, całość składa się z trzech wspomnianych wcześniej mniejszych sekcji reprezentujących odmienny styl i wymowę. Wbrew pozorom kolejną trudność może stanowić „podpowiedź" pozostawiona czytelnikowi w w. 2, mówiąca o tym, że historia przytoczona w ww. 3-10 jest zarówno zagadką (hîîâh ${ }^{12}$ ), jak i przypowieścią (māšāl). Po trzecie, występowanie w barwnym opowiadaniu bohaterów ze świata roślinnego i zwierzęcego jest zabiegiem alegoryzującym. Alegorie zaś pojawiają się w różnorodnych formach literackich i nie ma jakiegoś zamkniętego katalogu gatunków, dla których alegoria jest zabiegiem właściwym, decydującym o charakterze utworu ${ }^{13}$. Tego typu zjawiska pojawiają się m.in. w bajkach, opowia-

Niezależnie od braku zgodności opinii, czy ww. 1-10 są przykładem poezji, jak chcieliby tego tego Cooke, Zimmerli i Greenberg czy podniosłej prozy, według opinii Halsa, z pewnością ww. 11-21 odróżniają się znacząco stylem i terminologią od poprzedzającego go fragmentu. Ww. 1-10w większej mierze prezentująjęzyk poetycki i obrazowy niż następujący po nich tekst z 11-21.

11 Nie jest to jedyny przypadek stosowania alegorii w Księdze Ezechiela, ten zabieg literacki spotykamy także m.in. w Ez 16,1-63; 21,1-5; 23,1-49; 24,3-14. Z Ez 21,5 dowiadujemy się, że prorok był nazywany məmaššēl məšālîm - twórcą/opowiadającym alegorie/ /przypowieści. Por. J.St. Synowiec, Gatunki literackie w Starym Testamencie, s. 321-322.

12 Hîdâh w języku hebrajskim oznacza „węzeł”, w sensie przenośnym możne ten termin odczytywać jako zagadkę, aluzję, coś tajemniczego, ale też przypowieść.

13 W klasycznym spojrzeniu na alegorię jako zabieg literacki w Ez 1-21 mamy do czynienia $\mathrm{z}$ alegorią mieszaną (Kwintylian - permixta allegoria), tzn. taką, w której słuchacz/ 
daniach czy przypowieściach, tutaj przez obecność zwierząt i roślin najmocniej zbliżamy się do bajki ${ }^{14}$.

Ze względu na wspomniane trudności oraz w zależności od doboru akcentowanych treści komentatorzy biblijni decydują się na określanie Ez 17,1-10 mianem alegorii ${ }^{15}$, bajki ${ }^{16}$ bądź przypowieści ${ }^{17}$. Precyzyjne określenie gatunku tej opowieści wydaje się być niemożliwe, ze względu na duże pokrewieństwo tych terminów. Franz Sedlmeier w komentarzu do Księgi Ezechiela zauważa trudność w zdefiniowaniu rodzaju literackiego zawartego w Ez 17,1-10 i określa tę historię mianem alegorii bądź przypowieści $\mathrm{z}$ elementami alegorii ${ }^{18}$. Ez 17 może być przyczynkiem do bardzo szczegółowych badań nad gatunkami literackimi z tego względu, że ujawnia brak ostrych granic w stosowanych

czytelnik nie musi sam domyślać się znaczenia (jak w przypadku czystej alegorii - tota allegoria), lecz jest mu ono podane w dalszym tekście. Por. G. Kurz, Metapher, Allegorie, Symbol, s. 39.

14 Por. M. Golias, Bajka klasyczna, w: Słownik rodzajów i gatunków literackich, s. 74. Więcej na temat bajki i jej roli w tekstach starotestamentalnych zob.: A. Długosz, Kerygmatyczne znaczenie starotestamentalnych bajek, s. 50-60; J. Lemański, Bajka jako gatunek literacki w Starym Testamencie, s. 231-250.

15 Por. J. Czerski, Przypowieści Chrystusa jako gatunek literacki, s. 213; K-F. Pohlmann, Das Buch des Propheten Hesekiel Kapitel 1-19, s. 239; R. Rumianek, Księga Ezechiela. Tłumaczenie i komentarz, s. 148.

16 Por. W. Zimmerli, Ezekiel 1, s. 364; D.I. Block, The Book of Ezekiel, s. 526; M. Greenberg, Ezekiel 1-20, s. 318-319; L.C. Allen, Ezekiel 1-19, s. 254-255; R.M. Hals, Ezekiel, s.115.

17 Zdaniem Cooke’a mamy do czynienia z parabolą, jej wyjaśnieniem oraz obietnicą w ww. 22-24. Por. G.A. Cooke, A Critical and Exegetical Commentary, s. 181. 190. Simian-Yofre, podejmując próbę określenia gatunku literackiego wybranego fragmentu, w swoich analizach wyodrębnia ww. 1-10, pozostawiając otwartą kwestię ścisłej zależności ww. 1-10 i 11-24. Przy pominięciu interpretacji zagadki/bajki, która występuje po pierwszej części rozdziału 17, autor dochodzi do wniosku, że ww. 1-10 stanowią przypowieść, której nie muszą wyczerpywać dwie z podanych w rozdziale 17 interpretacji. Por. H. Simian-Yofre, Ez 17, 1-10 como enigma y parábola, Biblica 65 (1984) nr 1, s. 27-43. Spotykamy się też z opinią, że ww. 1-10 to zagadka w formie przypowieści. Por. J. Blenkinsopp, Ezekiel, s. 80; W. Eichrodt, Ezekiel. A Commentary, s. 223.

18 Por. F. Sedlmeier, Das Buch Ezechiel. Kapitel 1-24, s. 222. Inne próby łącznej, szerokiej odpowiedzi na pytanie o rodzaj literacki Ez 17 podjęli: Józef Homerski, który decyduje się na określenie „przypowieść alegoryzująca o charakterze politycznym”, por. Pismo Święte Starego i Nowego Testamentu w przekładzie z języków oryginalnych. Księga Ezechiela, Tłumaczenie, wstęp i komentarz J. Homerski, Biblia Lubelska, s. 69 oraz Janusz Lemański definiujący tekst jako „przypowieść o posmaku alegorycznym z wplecionymi elementami bajki". Por. J. Lemański, Izrael jako krzew winny i winnica Jahwe w tekstach Starego Testamentu, s. 235. 
przez autorów definicjach alegorii i przypowieści ${ }^{19}$. Ponadto różnice kulturowe i językowe nie pozwalają na jednoznaczne, klarowne wyjaśnienie podobieństw i różnic pomiędzy dzisiaj rozumianą alegorią i przypowieścią a zakresem znaczeniowym hebrajskiego terminu māšāl.

Należy zaznaczyć, że tym, co łączy wszystkich autorów zajmujących się Ez 17, jest zauważanie przez nich podobnego układu struktury całego rozdziału, dostrzeganie alegorii/bajki w ww. 1-10, wagi interpretacji w ww. 11-21 oraz teologicznego charakteru ww. 22-24, które zostały zredagowane później, nawiązując do terminologii pierwszej alegorii. Nawet jeśli w języku polskim nie określimy precyzyjnie gatunku literackiego omawianego tekstu jako bajki z interpretacją historyczną, czy też jako przypowieści lub rozbudowanej alegorii, z pewnością Ez 17 wpisuje się w znaczenie hebr. māšālu. Mamy tu do czynienia $\mathrm{z}$ opowieścią metaforyczną ${ }^{20}$, dyskursem obrazowym, a znaczenie szczegółowych elementów obecnych $\mathrm{w}$ alegorii $\mathrm{z}$ ww. 1-10 zostaje wyjaśnione poprzez interpretację zakorzenioną historycznie. Hebrajski rdzeń mšl jest powiązany z takimi znaczeniami jak „mówić przypowieściami”, „być podobnym”, „przypominać coś lub kogoss", wskazując na dyskurs, w którym chodzi o podobieństwa i porównania ${ }^{21}$. W Ez 17 mamy do czynienia z przeniesieniem cech i zachowań właściwych ludziom na bohaterów zwierzęcych i roślinnych (orły nie sadzą drzew ani nie uprawiają winnic).

\section{Dynamika Ez 17}

Niezależnie od tego, czy Ez 17,1-10 uznamy za bajkę, przypowieść czy rozbudowaną alegorię, nie sposób nie dostrzec, że alegoryczna opowieść o orłach, cedrze i winorośli stanowi podstawę i punkt odniesienia do następujących po niej sekcji 11-21 oraz 22-24. Dynamikę rozwoju treści rozdziału 17 bardzo przekonująco przedstawił Moshe Greenberg ${ }^{22}$, którego myśl podtrzymuje D.I. Block ${ }^{23}$.

Pierwszy z autorów zauważył, że ww. 11-21 stanowią dwustopniową interpretację alegorii z 1-10. Najpierw w ww. 12-18 ukazując jej znaczenie historyczne w odniesieniu do ziemskich władców, następnie w ww. 19-21

19 O dyskusji i zależnościach pomiędzy alegorią a przypowieścią zob. więcej: A. Paciorek, Przypowieść i alegoria - zarys problematyki, s. 353-363.

20 Thomas Renz określa treści Ez 17 jako „dyskurs metaforyczny”. Por. T. Renz, The Rhetorical Function of the Book of Ezekiel, s. 78.

21 Por. R. Meynet, Język. Przypowieści biblijnych, s. 12.

22 Por. M. Greenberg, Ezekiel 1-20, s. 320.

23 Por. D.I. Block, The Book of Ezekiel, s. 526. 
przedstawiając interpretację teologiczną - Boży zamysł dotyczący losów króla Sedecjasza. Wersety 22-24 zdaniem autora uznać należy za codę, ponieważ podsumowują cały rozdział, nawiązują do występującego wcześniej słownictwa, bohaterów pierwszej alegorii, ale zawierają nowe treści i podnoszą cały tekst Ez 17 na najwyższy poziom ${ }^{24}$. Dostrzeżenie wewnętrznej dynamiki tekstu pozwala czytelnikowi uchwycić zamysł autora i pomóc nam w udzieleniu odpowiedzi na pytanie, czy Ez 17 bardziej związany jest z tradycją mądrościową czy prorocką. Co zatem chciał powiedzieć „autor”?

Alegoryczna, zagadkowa opowieść z ww. 10 miała pobudzić zaintrygować słuchaczy, nakłonić do myślenia i spojrzenia na rzeczywistość z innej perspekty$w^{25}$. Nawet jeśli Ezechiel przejął istniejące wcześniej opowiadanie ludowe (bajkę $)^{26}$, to w tym przypadku posłużyła mu ona do zwrócenia uwagi odbiorców na aktualną sytuację narodu i postępowanie króla. Wersety 12-18 przynoszą wyjaśnienie na płaszczyźnie historycznej, ziemskiej. Dowiadujemy się, że pierwszy orzeł (nešer) oznacza Nabuchodonozora, wierzchołek cedru (șammeret ha' erez) - króla Jojakina deportowanego do Babilonu. Winorośl (gepen) to Sedecjasz ustanowiony władcą dla narodu pozostającego w Palestynie. Drugi orzeł to faraon, z którego wsparciem Sedecjasz planował bunt przeciw Nabuchodonozorowi $^{27}$. Ez 17 jest krytyką zgubnej dla narodu polityki Sedecjasza, ponieważ paktując z Egiptem, król złamał układ zawarty z władcą Babilonu.

Sekcja 19-21 podnosi interpretację na wyższy, teologiczny poziom. Ezechiel odczytuje złamanie umów z Nabuchodonozorem jako wyłamanie się z planów Bożych. Złamanie paktów zawartych z królem babilońskim jest tożsame ze złamaniem przymierza z Bogiem. Wersety 11-21 informują, że król i naród poniosą konsekwencje zdrady Sedecjasza. Wojsko, nawet pomimo pomocy Egiptu, zostanie pokonane, król zostanie pojmany i zabrany do Babilonu. Należy zaznaczyć, że terminy: król (melek w.12.16 ), przysięga ('ālāh

24 Autor zapożyczył termin coda ze świata muzyki. Coda (z wł. ogon) to fragment kończący utwór (najczęściej sonatę lub fugę) lub jego część, który materiałem nawiązuje do wcześniejszej tematyki dzieła. W niektórych przypadkach może wprowadzać nowy materiał tematyczny, odznaczać się kontrastem w stosunku do wcześniejszych fragmentów utworu. Por. Encyklopedia muzyki, red. A. Chodkowski, Warszawa 2006, s. 162. Block sekcję nazwaną codą określi również mianem „epilogu”. Por. D.I. Block, The Book of Ezekiel, s. 548.

25 Por. T. Renz, The Rhetorical Function of the Book of Ezekiel, s. 78.

26 Por. D.I. Block, The Book of Ezekiel, s. 523.

27 Więcej na temat polityki faraonów Neko, Psammetycha II i Chofry w odniesieniu do sytuacji Izraela i Palestyny oraz zawiązywaniu spisku antybabilońskiego w latach 592-591 zob: M. Greenberg, Ezekiel 17 and the policy of Psammetichus II, s. 304-309; A. Piwowar, Historia Izraela czasów Starego Testamentu, s. 167. 
w.13.18.19) a zwłaszcza przymierze (bərît w.13.14.15.16.18.19) ${ }^{28}$ zbliżają nas do tematyki bliższej nauczaniu proroków niż mędrców. Przymierze jako kategoria teologiczna jest bliska zarówno Ezechielowi, jak i współczesnemu mu Jeremiaszowi. Obaj (choć z innej perspektywy) krytykowali postępowanie Sedecjasza, prorocy mówili o łamaniu przymierza (Jr 22,9; 31,32; Ez 16,59; 44,7), ale też zapowiadali nowe przymierze, którego inicjatorem będzie sam Bóg (Jr 31,31; 32,40; Ez 16,60-62; 34,25; 37,26).

Zapowiedzi klęski Sedecjasza i upadku narodu spełniły się. Końcowe wersety 22-24, które powstały później, po zniszczeniu Jerozolimy ${ }^{29}$, są już słowami nadziei i pocieszenia. Przepowiadają odrodzenie się upadłego królestwa - Bóg sam zasadzi wierzchołek cedru (șammeret ha'erez) na górze Izraela. Drzewo rozrośnie się i stanie się schronieniem dla narodu. Treść końcowych wersetów rozdziału 17 mówi także o rozpoznaniu Boga przez wszystkie narody i Jego powszechnym panowaniu. Zapowiedzi odrodzenia i pomyślności z ww. 22-24 korespondują z innymi słowami proroka mówiącymi o pozytywnej odmianie losu narodu obecnymi w Księdze po rozdziale 33. Natomiast ww. 1-21 znajdują swoje odbicie w wymowie rozdziałów 15-23, które ukazują odpowiedzialność władców i ludu za upadek narodu i nadchodzącą klęskę Jerozolimy ${ }^{30}$.

\section{Ez 17 słowo proroka czy mędrca?}

Księga Ezechiela należy do pism prorockich Starego Testamentu, choć w jej treści pojawiają się nie tylko wizje prorockie (np. Ez 1-3) i wyrocznie kierowane przeciw Jerozolimie (np. Ez 21) i narodom ościennym (Ez 25). Prorok, w zależności od przekazu, który pragnie wygłosić i efektu, jaki chce wzbudzić w słuchaczach posługuje się różnorodnymi formami (po ich spisaniu możemy mówić o gatunkach literackich). Pojawiają się zatem w Księdze Ezechiela pieśni lamentacyjne (Ez 19), przysłowia (Ez 18,2) czy też omawiany rozdział 17, który stanowi przykład mowy metaforycznej - māšāl - rozumianego przez nam współczesnych jako rozbudowana alegoria, przypowieść czy bajka. Choć Ezechiel jest przede wszystkim prorokiem, przemawiając do rodaków, nie waha się sięgać po środki wyrazu właściwe mędrcom. Czyni to umiejętnie, z lekkością

28 Występowanie terminu bərît na kartach Starego Testamentu pokazuje największe zainteresowanie tematyką przymierza w księgach: Jozuego, Powtórzonego Prawa, I Kronik i Wyjścia. W księgach prorockich termin ten pojawia się łącznie 31 razy, w księgach mądrościowych (w Księdze Hioba i Przysłów w języku hebrajskim כִִִּ w w Mądrości Syracha

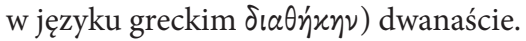

29 Por. J. Blenkinsopp, Ezekiel, s. 80.

30 Por. T. Renz, The Rhetorical Function of the Book of Ezekiel, s. 193-199. 
przechodząc od mowy metaforycznej do przedstawienia jej historycznej interpretacji, co zostało uwiecznione w spójnej formie literackiej. Prorok wygnania jest mówcą inteligentnym, elokwentnym i elastycznym.

Celem Ezechiela nie było wygłaszanie instrukcji dotyczących życia codziennego, dzielenia się mądrością zdobytą z doświadczenia pracy na roli, z życia małżeńskiego czy rodzinnego (co charakteryzuje pouczenia mędrców), ale wygłoszenie krytyki postawy Sedecjasza. Prorok zapowiada klęskę króla jako owoc niewierności przymierzu zawartemu z Nabuchodonozorem, a przez to pokazuje Boga jako władcę historii, który rządzi wydarzeniami także na arenie politycznej. Sekcja wieńcząca rozdział 17 zawiera treści eschatologiczne, zapowiada powszechne rozpoznanie Boga przez obce ludy, a także zapowiada odrodzenie narodu, dynastii Dawidowej, zawierając w sobie wątek mesjański ${ }^{31}$. Zarówno więc ww. 1-21 jak i 22-24 wpisują się w myśli podejmowane szerzej na kartach całej księgi. Ze względu na wymienione wyżej powody, a także pojawiające się w tekście charakterystyczne formuły prorockie, formułę rozpoznania niezależnie od wieloznaczności terminu māšāl, należy stwierdzić zdecydowanie, że 17 rozdział Księgi Ezechiela stanowi przykład nauczania prorockiego.

Jeśli poszukujemy wątków powiązanych z tradycją mądrościową, warto zaznaczyć, że wersety zamykające Ez 17 (ww. 22-24) odznaczają się treścią wybitnie teocentryczną. O ile z pierwszej alegorii za pomocą następującej szczegółowej interpretacji możemy domyślić się, w jakich czasach mogła zostać wygłoszona (przed upadkiem Jerozolimy, może nawet dokładniej ok. 592-591 roku przed $\mathrm{Chr}^{32}$ ), to sekcja końcowa nie odpowie nam na pytanie o historyczny czas przewidywanej interwencji Boga. Ostatnie wersety zbliżają Ez 17 do tekstów apokaliptycznych, mówią o bliżej nieokreślonej przyszłości pozostającej pod niepodważalną władzą Boga ${ }^{33}$. Jeśli szukać w Ez 17 wątków nawiązujących do myśli mądrościowej, to zbliżanie się do apokaliptyki może być tym, co wiąże tradycję sapiencjalną w jej szczytowej formie rozwoju ku wypełnieniu, jakim stały się pisma apokaliptyczne, z treścią Ez $17^{34}$.

31 Por. W.R. Osborne, The early messianic "afterlife” of the tree metaphor in Ezekiel 17:22-24, s. 166-167. Powtarzający się w tekście zwrot „wierzchołek cedru” odnosi czytelnika do postaci króla Jojakina, który dla Ezechiela jest prawowitym władcą narodu. Z nim są związane przyszłe obietnice odnowienia monarchii i pomyślności. Por. R.S. Foster, Note on Ezekiel 17:1-10 and 22-24, s. 379. Nawiązania do Jojakina ukazują rozdział 17 jako spójny z wymową Księgi Ezechiela. Por. Ez 1,2.

32 Por. M. Greenberg, Ezekiel 17, s. 309.

33 O wykorzystaniu bohaterów ze świata zwierzęcego i roślinnego jako zabiegu przybliżającym tekst Ez 17 do pism apokaliptycznych pisze Joseph Blenkinsopp. Por. J. Blenkinsopp, Ezekiel, s. 80.

34 Por. G. von Rad, Teologia Starego Testamentu, s. 598. 


\section{Bibliografia}

Allen L.C., Ezekiel 1-19, Word Biblical Commentary, Dallas 1994.

Blenkinsopp J., Ezekiel, Interpretation. A Bible Commentary for Teaching and Preaching, Louisville 2012.

Block D.I., The Book of Ezekiel: Chapters 1-24 NICOT Commentary, Grand Rapids 1997.

Brzegowy T., Pisma mądrościowe Starego Testamentu, Tarnów 2003.

Cooke G.A., A Critical and Exegetical Commentary on the Book Ezekiel, Edinburgh 1967.

Czerski J., Przypowieści Chrystusa jako gatunek literacki, Colloquim Salutis. Wrocławskie Studia Teologiczne 25 (1993), s. 209-230.

Długosz A., Kerygmatyczne znaczenie starotestamentalnych bajek, w: Studium Scripturae Anima Theologiae. Prace ofiarowane Księdzu Profesorowi Stanisławowi Grzybkowi, red. J. Chmiel, T. Matras, Kraków 1990, s. 50-63.

Eichrodt W., Ezekiel. A Commentary, Philadelphia 1970.

Encyklopedia muzyki, red. A. Chodkowski, Warszawa 2006.

Foster R.S., Note on Ezekiel 17:1-10 and 22-24, Vetus Testamentum 8 (1958) nr 4, s. 374-379.

Golias M., Bajka klasyczna, w: Słownik rodzajów i gatunków literackich, red. G. Garda, Warszawa 2012, s. 74-76.

Greenberg M., Ezekiel 1-20. A New Translation with Introduction and Commentary, Anchor Bible 22, New York 1983.

Greenberg M., Ezekiel 17 and the policy of Psammetichus II, Journal of Biblical Literature 76 (1957) nr 4, s. 304-309.

Hals R.M., Ezekiel, The Forms of the Old Testament Literature, Grand Rapids 1989.

Jezierska E.J., Mašal w tekstach Starego Testamentu, w: Patrzmy na Jezusa, który nam $w$ wierze przewodzi. Ksiega Pamiątkowa dla Księdza Profesora Jana Łacha w 85. rocznice urodzin, red. W. Chrostowski, Warszawa 2012, s. 185-196.

Kurz G., Metapher, Allegorie, Symbol, Göttingen 1982.

Lemański J., Bajka jako gatunek literacki w Starym Testamencie, w: Stworzył Bóg człowieka na swój obraz. Księga Pamiątkowa dla Ks. Bp. M. Gołębiewskiego, red. W. Chrostowski, Warszawa 2002, s. 231-250.

Lemański J., Izrael jako krzew winny i winnica Jahwe w tekstach Starego Testamentu, w: Duch i Oblubienica mówią: przyjdź. Księga Pamiątkowa dla o. Prof. Augustyna Jankowskiego, red. W. Chrostowski, Warszawa 2001, s. 220-239.

Meynet R., Język przypowieści biblijnych, Kraków 2005.

Osborne W.R., The early messianic "afterlife” of the tree metaphor in Ezekiel 17:22-24, Tyndale Bulletin 64 (2013) nr 2, s. 171-188.

Paciorek A., Przypowieść i alegoria - zarys problematyki, w: Ex oriente lux. Ksiega Pamiątkowa dla Księdza Profesora Antoniego Troniny w 65. rocznicę urodzin, red. W. Chrostowski, Warszawa 2010, s. 353-363. 
Pismo Święte Starego i Nowego Testamentu w przekładzie z języków oryginalnych. Księga Ezechiela, Tłumaczenie, wstęp i komentarz J. Homerski, Biblia Lubelska, Lublin 1998.

Piwowar A., Historia Izraela czasów Starego Testamentu. Od patriarchów do podboju przez Rzymian, Lublin 2013.

Pohlmann K.-F., Das Buch des Propheten Hesekiel Kapitel 1-19, Das Alte Testament Deutsch 22/1, Göttingen 1996.

Rad von G., Teologia Starego Testamentu, Warszawa 1986.

Renz T., The Rhetorical Function of the Book of Ezekiel, Suplements to Vetus Testamentum, Leiden-Boston-Köln 1999.

Rumianek R., Księga Ezechiela. Tłumaczenie i komentarz, Warszawa 2009.

Sedlmeier F., Das Buch Ezechiel. Kapitel 1-24, Neuer Stuttgarter Kommentar. Altes Testament 21/2, Stuttgart 2002.

Simian-Yofre H., Ez 17, 1-10 como enigma y parábola, Biblica, 65 (1984) nr 1, s. 27-43.

Synowiec J.St., Gatunki literackie w Starym Testamencie, Kraków 2003.

Zimmerli W., Ezekiel 1. A Commentary on the Book of the Prophet Ezekiel, Chapters 1-24, Philadelphia 1979. 